\title{
The Influence of Empowerment and Community Participation towards the Improvement of Community Welfare Recipient Community Empowerment Program Based in the City of Pekanbaru Riau Province
}

\author{
Azharisman Rozie \\ Institut Pemerintahan Dalam Negeri, Indonesia
}

Received: Aug 1, 2018 Accepted: Aug 28, 2018 Online published: Sep 11, 2018

doi:10.5296/jpag.v8i3.13460

URL: https://doi.org/10.5296/jpag.v8i3.13460

\begin{abstract}
The phenomenon used as the object of this research is to improve the welfare of beneficiaries of PMB-RW Program in Pekanbaru City. This research design uses quantitative less qualitative dominant. Quantitative analysis with a sample of 360 respondents using SEM analysis method then SEM analysis results conducted qualitative analysis using descriptive analysis developed by Observer and Triangulation Analysis method from quantitative analysis with 4 informant research determined by purposive sampling. The conclusion of this research is that there is the influence of Empowerment to Improvement of Welfare of Beneficiary Society with the result of measurement coefficient of path reach 0,78 , enter "strong" and significant category. The influence of Community Participation on the Improvement of Welfare of Beneficiary Society with the result of measuring the coefficient of lane 0.73 , entering the category of "strong" and significant. From the measurement result of multiple regression coefficient, it is known that the contribution of the influence of empowerment $(0,594)$ is bigger than the contribution of Community Participation $(0,543)$ to Improvement of Welfare of PMB-RW Program Relief Society. While the development of the concept obtained is the development of the concept of the Dimensions of Opportunities for Community Empowerment and the development of the concept of Community Participation in Various Development Work. Advice authors to improve the welfare of beneficiaries is done by enhancing, improving and optimizing the performance of the empowerment and participation of active community involvement.
\end{abstract}

Keywords: empowerment, community participation, improvement of community welfare 


\section{Introduction}

One of the considerations which underlie the publication Act No. 23-year 2014 about local governance is that of organizing local governance is directed to expedite the attainment of community welfare through increased service, empowerment, and participation of the community, as well as increased competitiveness of the area having regard to the principles of democracy, equity, justice, and the idiosyncrasies of an area in a unitary State system of the Republic of Indonesia. With the consideration that then the purpose of the implementation of the policy decentralization and regional autonomy as set forth in Act No. 23 of the year 2014 are realizing the welfare of society. Community welfare is achieved by organizing the Affairs of Government.

In order to decrease the number of poor population, specifically, The Government is working to improve the welfare of the city of Soweto communities with Community-based Empowerment Program hosted an RW or-RW PMB abridged. The vision of the PMB-RW is "Embody civil society Pekanbaru that starts from the tenets of the citizens". The meaning of this vision are as follows: first, the sense embody ideals is the leader of the city of Pekanbaru with through a process of lengthy so Tridaya materializes the Community pillars, prosperous and a clean environment, healthy and beautiful; second, the meaning of civil society is the end result of a long process of both the empowerment approach resulting in public order quality i.e. society independent, resilient and Competitive Power locally, nationally or internationally at the start of the city of Pekanbaru. With that vision, established the Mission of PMB-RW. The Mission of the PMB-RW as follows: first, to carry out a program must have planning supported by existing data in each RW includes a map and Demographic Data, Rona Plans Setup Area (RPK RW); and second, the results of the implementation process of Tridaya (Social Empowerment, economic empowerment, and empowerment of the creative arrangement of the environment) is expected to take shape civil society.

With the policies and the concept of Program PMB-RWs implementing, efforts increased the welfare of society in environmental RW seems to be a phenomenon of the execution of the Affairs of the Government with regard to basic services. The phenomenon is certainly not escaped the influence of a variety of variable. Of a number of variables that affect the improvement of community welfare in the city of Pekanbaru, the author had a basic assumptions (assumption) that the community empowerment organized through Program implementation PMB-RW and participation of the community in the process of implementation of the programs into two variables that influence on the improvement of community welfare in the city of Pekanbaru. The basic assumption is based on the premise that the major as follows:

First community empowerment, which includes social empowerment; economic empowerment; and empowering environment that progress in the implementation of the Program of PMB-RW is a series of reinforcement of the resources of citizens to improve well-being. Therefore, the community empowerment is functionally correlated and or positive effect (line) towards the improvement of the well-being of the community through reinforcement. Second, a wave of community participation in the implementation of 
PMB-RW Program is a series of citizen engagement in community and public institutions in the implementation of the program. Thus, public participation is functionally a positive effect towards the improvement of the welfare of the community.

Third, in the context of the disability, when the empowerment and Participation of the community is positioned as an antecedent variable (which preceded, because), and an increase in the welfare of society is positioned as a variable consequences (phenomenon, result), then it ought to be hypothesized that in between empowerment and community participation with an increase in the welfare of the poor is created a mechanism of causality relationship. This hypothesis certainly needs to be tested.

\section{Literature Review}

\section{Empowerment}

Empowerment or empowerment is a concept that the focus is power (power). Empowerment of any assumption is accepting the existence of power as a factor and made the ruling not having power, that the powerless are given power through the empowerment so that it becomes powerful. (Pranarka, 1996:261-262). Furthermore, Ife (1995:62) also suggests that that empowers communities to contain the meaning of developing, in-depending, self-helping, and strengthen the bargaining position of the lower layers of society against the regime in all fields. In line with this opinion, Shardlow (1998:32) suggests that: "Empowerment is centrally about people taking control of their own lives and have the power to shape their own future. According to Shardlow, empowerment is about people who take control of their own lives and have the power to determine their own future.) Thus, if the Community (both individual and group) has undergone a process of empowerment is then expected they would be able to control their own lives and cultivates future in accordance with their wishes.

Overview of the process of empowerment in more has been said by Kartasasmita (1996:144), as follows:

In an effort to give strength and ability, means for the empowerment of the parties contains two needs to be reviewed carefully, namely those who are empowered and empowering. In order to obtain results that satisfy the required high commitment from both parties. The empowerment had to depart from the approach that the public not is made the object of a variety of program and project development but are subject to the development efforts of its own. For that, it is in community empowerment, should follow the directional approach, implemented by communities that become target groups and use Group approach.

The empowerment strategy can be defined as a certain way of doing the various approaches to achieving the goals and objectives of empowerment. According to Sedarmayanti (2003:112):

To be able to create a society that is capable of supporting the implementation of development programs required a strategy of empowerment through the development of creativity, innovation, and utilization of intellectual capital as the Organization's new wealth to face time future. 
Creativity is a series of activities that are sourced from the development of a concept of a new idea. Problems often encountered in the process of empowerment is influencing how the party needs to be empowered by promoting certain ideas in order to receive and actualize the ideas. For it is necessary that approach strategies according to Susanto (Beratha, 1982:50), including:

1. The strategy of persuasion, where paramount initially was held a change of the attitude of a person or group of people;

2. The strategy of compulsion, provision of the situation in such a way that people forced to indirectly change his attitude;

3. The strategy of pervasion, repeating what was expected to be entered in a field of one's subconscious so that changing the attitudes themselves according to what is repeated.

4. The strategy of coercion, forcing directly procure a change in attitude by the existence of physical or legal matter.

Shardlow (in Adi, 2002; 54-55) says "empowerment is centrally about people taking control of their own lives and have the power to shape their own future". Empowerment is about people who take control of their own lives and have the power to organize their own future. Empowerment is a series of plot development effort that includes a number of phases. In this context, Adi (2001:173) suggests the stages of community development which includes the stages of preparation, the assessment stages, the stages of alternative program or activity planning, the stage of the action plan formulating, stages of program implementation or activity, the stages of evaluation, and termination stages.

Preparation phase. Human resources this preparation inside the stage set-up officer (a) and (b) the preparation of the field. Preparation of the clerk (in this case labor community worker) is a requirement of the success of a community development approach to the non-directive. The preparation of these officers especially in the need to equate perception between members of the team agent-changer (change agent) regarding the approach to what will be in select in doing community development. Preparation of more officers needed more violins in the process of developing energy Officer (community worker) elected turned out to have very different backgrounds to each other. (Adi, 2001:173)

Stages Assessment. The assessment process is conducted here is done by identifying the problem (the perceived needs $=$ felt needs) and also the resources that belong to the client. In addition, in the process of valuation (assessment) of these SWOT techniques can also be used to look at the strength (strength), weakness (weakness), chance (opportunities) and threats (threat). (Adi, 2001:174)

Stage Perencanan Alternative Programs Or Activities. At this stage the officer (community worker) for participating and try to involve citizens to think about problems they face and how to overcome it. In an effort to overcome the existing problems of society are expected to be able to think of some alternative programs and activities that they can do. (Adi, 2001:174)

The Stage Of The Pemformulasian Action Plan. At this stage, the change agents (community 
worker) helps community groups to formulate their ideas in written form, especially when there is a linked with a proposal making to the person's funds. Help from party officials usually sorely needed on a group that has never put forth a proposal to funders. But for a group that once several times apply then the officer's role became more reduction. (Adi, 2001:175)

Stages of Implementation (Implementation) the Program or activity. This implementation phase is one of the most crucial stages (with clubs) in the process of development of society, as something already well planned will be sidetracked in the implementation in the field when not there is cooperation between the citizens. The conflict between groups of citizens could also hinder the implementation of a program or activity. for example, when there is an informal character of the newly turned out at this stage turned out to oppose the program offered by the citizens who are actively involved in the planning process. (Adi, 2001:175)

Evaluation Phase, evaluation as a process of scrutiny from residents and officers for running program on community development should be done by involving citizens, with involvement at this stage expect will form a system in the community to conduct surveillance internally. So, in the long term are expected to be able to form a system in a society that is more 'independent ' by utilizing existing resources. But sometimes the results of monitoring and evaluation of the results achieved did not turn out as expected. (Adi, 2001:176)

Termination Phase. Termination is done is often not because the community can already be considered "independent", but not rarely happens because the project must be stopped because it has exceeded the specified time period before, or because the budget is over and No funders can and want to continue. Nevertheless, it is not uncommon for community worker remained in contact even though it was not on a routine basis. Especially when the officer (community worker) feels that the task has not been completed properly. This step as it also stages the planning change made by Lippit, cyclical creation raises stages was common (cyclical) that can be spun like a cycle in order to achieve a better chance, especially after evaluation process (monitoring) towards the implementation of the activity. (Adi, 2001:178)

From the description of the theory of community empowerment, the author chose the theory of community empowerment by Ife (1995:182) that says: "Empowerment means providing people which it was resource opportunities, knowledge, and skills to increase their capacity to determine their own future, and to participate in and affect the life of their community". Based on this conceptual definition drafted empowerment variable that Empowerment is the provision of resources, expertise, knowledge, and opportunities to the citizens of the community recipient Program PMB-RW in order to increase the capacity of citizens to determine the future and participate in public life. From the definition of derived four dimensions of discussion: (1) the dimensions of the provision of resources, (2) the dimensions of the provision of opportunities, (3) provision of knowledge and Dimensions (4) dimensions of the provision of expertise. The four-dimensional discussion developed into 12 indicators to provide the manifest variables 12 .

\section{Community Participation}

Community empowerment through community empowerment Program execution-based RW 
certainly closely related to public participation in the implementation of the program. Many definitions of participation presented the experts. In terms of this participation, Oakley, (1991:6) says "Participation is considered a voluntary contribution by the people in one or another of the public programmers supposed to contribute to national development, but the people are not expected to take part in shaping the programme or criticizing its contents".

Public participation seemed to be an important element in the development of the community. According to the Adi (2003:298) community involvement is not just seen in the stage of planning and execution, but already extends to the stage of assessment and evaluation. The stage is the Adi include (1) the stage of the assessment; (2) the planning stages alternative programs or activities; (3) Implementation Phase (implementation) the program or activity; and (4) the evaluation Phase (including the evaluation of the input, process, and outcome). Further explained that with the approach of the consensus of the community development, empowerment process is done in an effort to make the community become more eloquent mainly relates to handling the problems that appear in the community.

To be able to see the form of community participation, it can be noted the opinions of Participating (Amaluddin, 1987:2) that distinguishes public participation in the decision-making process by virtue of its nature, namely, consultative in nature and our partnership. Consultative Participation occurs between the officials' decision makers with community groups with an interest. Members of the public have the right to be heard his opinion and to be told, but final decisions remain in the hands of decision makers. While public participation which is a partnership, the official decision makers and members of the community is relatively parallel partners its position. They together discuss, looking for an alternative problem solving and decision making.

In line with the various meanings of participation which is expressed, Kramer (in Sutomo, 1995:134-135) says there are 4 forms of participation, i.e.:

1. Participation in decision-making, that are involved in the decision-making process, it is expected the interests and problems will be reflected in the program made;

2. Participation in the development of the program, that the community as a target group is a program, then consumers need to hear opinions and advice especially about needs and interests as well as real aspirations;

3. Participation that emphasizes engagement in social movements, in which the community as a powerless party can become a pressure group is effective;

4. Participation in the form of engagement in a variety of jobs, that communities that have no other alternatively in her work, then it can work to get opinions through the program.

With regard to the purpose of public participation, Ndraha (1990:67) says that the purpose of community participation in development is:

a. Cultivate, maintain, or taking care of all your resources, assets and infrastructure in the form of either a physical or a nonphysical; 
b. Rebuild the spirit of the society of the State of falling backward as a result of actual confusion ever reached;

c. The community can give a positive response to any social change that is underway;

d. The community can develop and improve our resources, assets or equipment that is in the process of development.

From the explanation of the theory of participation selected opinions of Kramer (in Sutomo, 1995:134-135) which says there are 4 forms of participation, i.e.:

1. Participation in decision-making, that are involved in the decision-making process, it is expected the interests and problems will be reflected in the program made;

2. Participation in the development of the program, that the community as a target group is a program, then consumers need to hear opinions and advice especially about needs and interests as well as real aspirations;

3. Participation that emphasizes engagement in social movements, in which the community as a powerless party can become a pressure group is effective;

4. Participation in the form of engagement in a variety of jobs, that communities that have no other alternatively in her work, then it can work to get opinions through the program.

Based on the theory of the participation of the above definition drafted Kramer conceptual variable that Community participation is the active involvement of citizens in the process of implementation of the PMB-RW Program expressed with participation in decision-making, participation in program development, participation in the social movement, and participation in the implementation of various jobs. The conceptual definition of this variable retrieved the four dimensions of discussion: (1) the dimension of participation in decision making, (2) the dimension of participation in program development, (3) participation in the social Dimension, and (4) Dimensions participation in the implementation of various jobs. The fourth dimension is developed into 12 indicators to provide the manifest variables 12 .

\section{The Welfare Society}

The welfare of society is a welfare or a specific standard of living (levels of living) that is achieved by organizing the various development efforts and community empowerment to overcome poverty. That is, the community welfare can be achieved when society itself free from the problems of poverty. In the context of this understanding of the problem of poverty will be important to assess the extent of a society living in one area. According to Kartasasmita (1993:50), the knowledge about the characteristics of poverty has a meaning that is essential for the formulation of policies in poverty reduction. According to Sumodiningrat (1999:2), in General, poverty as measured by income level and needs. If income levels do not meet the minimum requirements, then such person or household is said to be poor.

The poor are generally weak the of the endeavor and the limited access to economic activities so that the more left away from other communities that have higher potential. Therefore, 
Kartasasmita (1993:64) said that poverty was a deficient situation that occurred not because of the caused by the poor, but because of the inevitable with the power that they have. Conceptually, poverty can be seen qualitatively i.e. is a condition of human life that is not dignified or by other adequate understanding of human life is not feasible according to the values of humanity. Quantitatively, poverty is a situation where humans live lean, because of low productivity, lack of income and very limited the ability of the economy to meet the necessities of life. In this context Sutrisno (1997:16) says:

In the empirical, a myriad of factors that cause the occurrence of poverty such as the culture that is associated with low work ethic, injustice associated with the ownership of the factors of production such as land ownership is uneven. But some are saying that the only development model oriented to a country's economic growth would cause poverty to a bunch of people.

Kartasasmita (1996:240-250) says that there are several causes of poverty, but generally described as follows:

1. Low levels of education, low levels of education lead to limited self-development capability and cause lack of employment that can be accessed. In competing to get jobs there are, determines the education level. Low education levels also limit the ability to seek and exploit opportunities;

2. The low degree of health, wellness and nutrition levels are low, causing the low physical endurance, intellect, and initiatives;

3. The limited employment opportunities, a State of poverty because of the condition of education and health is hard by the limited field of work. As long as there are employment or business activities, during this time there is hope to break the circle of poverty that;

4. Isolated Conditions, many residents are poor, economically powerless because of the remote and isolated. They lived secluded, making it difficult or may not be affordable by the ministries of education, health, and motion of progress enjoyed by other people.

Still in line with the opinion above, Chambers (1983:111) using the integrated concept (integrated poverty) to understand the problem of poverty in developing countries. In contrast to other rural development experts, Chambers saw that poverty experienced by the people who are developing, especially the rural folk, is caused by some factors that are called "Unfortunately" or disadvantage are interlinked with each other. Chambers (1983:111) explains that unfortunately that circle of life people or poor families are:

1. Poverty, it is characterized by the fulfillment of the needs of clothing, food, Board that inadequate and insufficient income daily needs;

2. Weaker physical, namely the existence of a high dependency ratio between family members, in this case, make a living; 
3. Vulnerability, is usually poor families do not have a good backup in the form of money or food to cope with emergencies;

4. Splendid isolation covering geographically as well as alienation of social alienation;

5. Powerlessness, Poor people do not have the power/strength to deal with people who are more powerful (powerful) who often exploit them.

To understand the objective conditions of poverty, then poverty condition of classification is required. Kartasamita (1993:2), distinguishing poverty from income level:

First absolute poverty, i.e. the level of income or the amount of income that is not enough to meet the minimum necessities of life, such as food needs, clothing, health care, housing, and education. Second, the relative poverty i.e. State comparisons between groups of people with an income level that is already above the poverty line so that it does not include the poor poorer, but still compared to other community groups.

Deeper Kartasamita (1993:3), describes the poverty which can be distinguished into three following notions:

First poverty, natural (natural) State of poverty because of its origin is indeed poor. The group is poor because it does not have the adequate resources, both natural resources, human resources, as well as other resources. Secondly, the structural poverty, poverty caused by the acquisition of income inequality in a society that is not balanced which then cause the structure of the society which was lame. Third, this cultural poverty refers to a person's or the public's attitude caused by living habits, lifestyle and culture, they already feel the adequacy and not feel the lack. This group is not easy to be invited to participate or to make changes to improve the level of life thus causing their income is low according to a common size used.

Clearer again, Kartasasmita (1993:18-19) said that when examined from the pattern of time, poverty in a region can be classified as follows:

The first Pattern is "Persistent poverty, i.e. the poverty which has been hereditary. The area, in General, is critical areas of natural resources or isolated areas. The second pattern is cyclical poverty, i.e. the poverty that followed the pattern of the economic cycle as a whole. The third is the pattern of seasonal poverty i.e. a seasonal poverty as often encountered in the case of fishing and farming food crops. The last was the accidental poverty i.e. poverty due to the occurrence of a natural disaster or the impact of an erroneous policy which caused the decrease in the level of well-being of a society.

According to the World Bank (in Sumodiningrat, 1999:2), the State of the poor as "Poverty is a concern with the absolute standard of living of the poor part of social inequality refers to relative living standards across the whole society". With an understanding of the other, poverty can be measured by comparing the income level of people or households with income levels required to meet the minimum requirements. The basic concept of the poverty line (poverty line) for this is set based on the magnitude of spending in order to meet the basic needs of a person in 
order to be able to live normally. The poverty line is expressed in units of per-capita monthly income.

The poverty of many associated with the issue of the economy. The characteristics of the issue of the economy in one country with other countries is certainly different. Similarly, the characteristics of the issue of the economy in a region different from other areas. Nevertheless, according to Todaro and Smith $(2003,55)$ :

We must also strive to uncover and understand the commonalities. the characteristics of the economy of developing countries for the sake of allowing us to get a form of general analysis framework that can be applied to study the developing countries as a whole or as a whole.

Thus, the analysis of the problem of poverty in a country or region needs to be linked to the economy's condition in the country or the region. Depart from the issue of the economy in developing countries, according to Todaro and Smith (2003, 55), briefly and simply, the General characteristics of the problems of poverty in developing countries can be classified into six categories as following: (1) a relatively low standard of living, demonstrated by low income levels, income inequality and a severe health condition is bad, and lack of system educators; (2) the low level of productivity; (3) the rate of population growth as well as a high dependency burden; (4) a very large income Dependency to the production of the agricultural sector as well as the export of primary products (raw materials); (5) a market that is not perfect, and the limited information available; and (6) dominance, dependence, and severe fragility on almost all aspects of international relations.

From the above reasoning can obviously pull a proposition that low productivity cause of low income. Low-income cause purchasing power becomes low. The low purchasing power of a clear result in difficult achieve the expected standard of living. In this context, Todaro and Smith $(2003,56)$ reveal:

In almost all developing countries living standards (levels of living) of most of its inhabitants tend to be very low, not only compared to the living standards of people in rich countries, but also with style the elites in their own countries. Low standards of living that are manifested in the form of quantitative and qualitative levels of very low income (poverty), less decent housing, poor health, lack of education is minimal or even no same Once, high infant mortality, age of life expectancy is relatively short, the chance of getting a job are low, and in many cases, there is also dissatisfaction and helplessness in General.

From the phrase Todaro and Smith found that the quantitative and qualitative issues of poverty among other identified from (1) to a very low level of income, (2) a less worthy the housing, (3) poor health, (4) the provision of minimal education or even none at all, (5) high infant mortality, (6) the age of life expectancy is relatively short, and (7) the chances of getting a job are low. The problems of poverty this is what causes the community welfare or standard of living becomes lower. That is, implementation purpose of the policy of decentralization and regional autonomy which is translated with the expansion of the area and the performance of local government must be able to resolve the problems of poverty because the purpose of the 
implementation of the policy decentralization and regional autonomy embody the welfare of society. For that, the Government needs to do a variety of human resource development efforts and community empowerment.

From the description of the theory of well-being presented selected theory of levels of living are raised by Todaro and Smith $(2003,56)$ as theoretically based on the preparation of operational concept variable Welfare society. Todaro and Smith $(2003,56)$ say:

In almost all developing countries living standards (levels of living) of most of its inhabitants tend to be very low, not only compared to the living standards of people in rich countries, but also with style the elites in their own countries. Low standards of living that are manifested in the form of quantitative and qualitative levels of very low income (poverty), less decent housing, poor health, lack of education is minimal or even no same Once, high infant mortality, age of life expectancy is relatively short, the chance of getting a job are low, and in many cases, there is also dissatisfaction and helplessness in General.

With the Foundation of the theory of levels of living are arranged the definition of conceptual variable that the welfare of the community is a dynamic condition of the attainment of the standards of living standards (levels of living) Ogan Ilir Regency society that stated income, housing, health, education, infant mortality, life expectancy and Age the chance of getting a job. Conceptual definitions Of variables retrieved seven dimensions study of:(1) the dimensions of income, (2) Housing Dimensions, (3) dimensions of health, (4) dimensions of education, (5) dimensions of infant mortality, (6) dimensions of Age life expectancy, and (7) the dimensions of the chance of getting a job. The seven dimensions the study later developed into 21 indicators research for 21 items to research questionnaires submitted to the respondents who became the research sample.

\section{Methodology}

Research using a quantitative research approach. There are 36 item questionnaires with Likert scale drawn up were given to a sample of the research. Sample research as much as 360 respondents taken with the technique of 36 item questionnaire multiplied by 10 Miles and Matthew, 1992:332). Sampling distribution of each sub-populations using Stratified Random Sampling Technique. Secondary data collection using the study of librarianship, the collection of primary data of the respondent research using questionnaires, Observation, and Interview Guidelines. Data analysis using SEM and regression analysis. The results of the statistical analysis descriptive analyses developed to research findings obtained the basic concept of development.

The population used to research is the apparatus and local people involved in the process of implementation of the Program of PMB-RW. The population consists of the entire apparatus of the Agency's community empowerment and family planning (BPPMKB) the city of Soweto as a leading sector community empowerment activity; the entire Head and the whole Head in the city of Pekanbaru and community groups that became the driving force and the recipient community empowerment in 610 Pillars Residents in Pekanbaru. The number of 


\section{Macrothink}

elements and the overall population of the research are as follows:

Tabel 1. Population Research

\begin{tabular}{cll}
\hline No. & \multicolumn{1}{c}{ Sub Population/Unit Analysis } & \multicolumn{1}{c}{$\begin{array}{c}\text { The total number } \\
\text { of }\end{array}$} \\
\hline 1 & Apparatus BPPMKB Pekanbaru & 35 \\
2 & Sub-District Head in Pekanbaru & 12 \\
3 & Lurah in Pekanbaru & 58 \\
4 & The Driving Group P MB-RW & 610 \\
5 & Citizens of Recipient Groups P MB-RW & 610 \\
& Total & $\mathbf{1 , 3 2 5}$ \\
\hline
\end{tabular}

The magnitude of the sample in this research is determined from the number of indicators that have been defined in this study. According to Miles and Matthew (2002:332), that for the analysis of Structural Equation Modeling (SEM) great samples of the research revolves around 100-200 or 5-10 times the number of variables in the manifest (indicators) of overall latent variables. Based on the concept of the SEM, the number of indicators in this study is as much as 36 indicators, thus the number of samples specified is of 360 samples. To determine the distribution of sampling from each sub-population/unit analysis, used Stratified Random Sampling Technique. This technique requires a unit called the sample fraction (f) for each subpopulation as a leverage factor, where the number of the sample fraction is adapted to the number of the level by using the magnitude of sampling fraction per stratum is the following:

$$
f_{i}=\frac{N_{i}}{N}
$$

Then come by the magnitude of sub-sample per stratum:

ni $=$ fi. $n$

Description:

$\mathrm{f}_{\mathrm{i}}=$ sampling fraction stratum $\mathrm{i}$

$\mathrm{N}_{\mathrm{i}}=$ the number of individuals present in the stratum of population elements work

$\mathrm{N}=$ the number of individuals of the population entirely

$\mathrm{n}=$ the number of respondents that are inserted into the sample

$\mathrm{ni}=$ the number of respondents who entered into a sub-sample/stratum

Based on the above formula, then the distribution of sampling from each unit of analysis/sub populations are as follows:

\section{Apparatus BPPMKB Pekanbaru:}

$$
f_{i}=\frac{N_{i}}{N}=f_{i}=\frac{35}{1325}=0,026
$$

$\mathrm{n}_{\mathrm{i}} \mathrm{f}=\mathrm{i}_{\mathrm{i}} \cdot \mathrm{n}=0.026(360)=9.36$ rounded 9 Respondents

Sub-District Head in Pekanbaru : 


$$
f_{i}=\frac{N_{i}}{N}=f_{i}=\frac{12}{1325}=0,905
$$

$\mathrm{n}_{\mathrm{i}}=\mathrm{f}_{\mathrm{i}} \cdot \mathrm{n}=0.905(360)=3.25$ rounded 3 respondents

\section{Lurah se Pekanbaru:}

$$
f_{i}=\frac{N_{i}}{N}=f_{i}=\frac{58}{1325}=0,043
$$

$\mathrm{n}_{\mathrm{i}}=\mathrm{f}_{\mathrm{i}} \cdot \mathrm{n}=0.043(360)=15.48$ rounded up 16 respondents

\section{Group Movers PMB-RW Program :}

$$
f_{i}=\frac{N_{i}}{N} \quad=f_{i}=\frac{610}{1325}=0.460
$$

$\mathrm{n}_{\mathrm{i}}=\mathrm{f}_{\mathrm{i}} \cdot \mathrm{n}=0.460(360)=165.6$ rounded 166 Respondents

\section{Group Of The Citizens Of The Recipient PMB-RW Program :}

$$
f_{i}=\frac{N_{i}}{N}=f_{i}=\frac{610}{1325}=0.460
$$

$\mathrm{n}_{\mathrm{i}}=\mathrm{f}_{\mathrm{i}} \cdot \mathrm{n}=0.460(360)=165.6$ rounded 166 Respondents

Next, tally distribution sampling from each sub-population/sample analysis by unit 360 respondents is as follows:

Table 2. Sample Research

\begin{tabular}{ccc}
\hline No. & Sub Population/Unit Analysis & $\begin{array}{c}\text { The total } \\
\text { number of }\end{array}$ \\
\hline 1 & Apparatus BPMKB Pekanbaru & 9 \\
2 & Sub-District Head in Pekanbaru & 3 \\
3 & Lurah in Pekanbaru & 16 \\
4 & Group Movers PMB-RW Program & 166 \\
5 & Group of The Citizens of The Recipient & 166 \\
PMB-RW & 360 \\
\hline
\end{tabular}

Source: Calculation Results

\section{Result and Discussion}

The Influence of Empowerment Against the Welfare of the Community

Measuring results influence Empowerment against the welfare of society reached 0.78 . The magnitude of the influence of Empowerment against the welfare of society is determined by the provision of Resources, provision of opportunities, the provision of knowledge, the 
provision of knowledge, the provision of expertise. Contribution to the influence of the expansion Area against the welfare of the community is quite strong. It is also revealed from the magnitude of the measurement results which showed the determination coefficient $\mathrm{R}^{2}=$ 0.61 the rest of 0.39 is the contribution of latent variables (tetha epsilon).

In a practical perspective, the magnitude of the influence of Empowerment against the welfare of society is formed by 12 manifest variables (observed variable) empowerment. Twelve manifest variables in question is (1) mentoring resources, (2) capital resources, (3) environmental resources, (4) propose Opportunities, (5) Opportunities got the support of capital and business facilities, (6) Opportunities try and earn income, (7) practical knowledge of business capital, (8) practical knowledge, product management and marketing, (9) practical knowledge of financial management, (10) the skill of making products, (11) expertise to market the product, (12) Skills earn income.

In the theoretical perspective, the magnitude of influence towards the empowerment of community welfare Recipient Program PMB-RW is determined by the dimensions of the empowerment theory of Ife. Ife (1995:182) that says: "Empowerment means providing people which it was resource opportunities, knowledge and skills to increase their capacity to determine their own future, and to participate in and affect the life of their community". With the theory of Empowerment is conceptualized as the provision of resources, opportunities, knowledge, and expertise to the citizen's recipient Program PMB-RW in order to increase capacity for these citizens to determine the future and participate in public life. With the concept of operations developed variable 4-dimensional analysis: (1) the dimensions of the provision of resources, (2) the dimensions of the provision of opportunities, (3) provision of knowledge and Dimensions (4) dimensions of the provision of expertise.

\section{The Influence of Public Participation towards Community Welfare}

Measuring results influence public participation towards achieving community welfare amounted to 0.73 . The magnitude of the influence of public participation against the welfare of society is determined by the problem identification, formulation of the problem, the solution of the problem, program planning, mobilizing the resources of programs, program implementation, submission of proposed activities, program implementation, support activities, implementation activities, making the road the environment, the provision of social facilities, the provision of public facilities. Contribution to the influence of public participation against the welfare of the community is quite strong. It is also revealed from the magnitude of the measurement results that showed the determination of the coefficient of $\mathrm{R}^{2}=0.530 .47$ of Rest is contributed to the influence of latent variables exogenous (tetha epsilon). Latent variables exogenous in question is variables are also assumed to affect the welfare of society but not examined.

In a practical perspective, the magnitude of the influence of public participation against the welfare of society is formed by 12 manifest variables (observed variable) public participation. Because of the proven and tested that community participation is a positive and significant effect against the welfare of the community, then the community welfare Recipient Program PMB-RW can be improved by increasing The Participation Of The Community. Increased 
public participation can be done by optimizing the 12 indicators of community participation. Twelve indicators referred to (1) identify the problem, (2) the formulation of the problem, solutions to problems (3), (4) the planning of the program, (5) Raising resources program, program execution (6), (7) Submission The proposed activities, (8) support activities, (9) Implementing, (10) the making of the road environment, (11) the provision of social amenities, (12) the provision of public facilities.

In the theoretical perspective, the magnitude of the influence of the Society Participation towards the welfare of society Recipient Program PMB-RW is determined by the theoretical dimensions developed from the theory of the participation of the community of Kramer (in Sutomo, 1995:134-135) which says that there are 4 forms of participation, namely: (1) Participation in decision-making, that are involved in the decision-making process, it is expected the interests and problems will be reflected in the program made; (2) Participation in the development of the program, that the community as a target group is a program, then consumers need to hear opinions and advice especially about needs and interests as well as real aspirations; (3) the participation of the emphasis on involvement in social movements, in which the community as a powerless party can become a pressure group is effective; (4) Participation in the form of engagement in a variety of jobs, that communities that have no other alternatively in her work, then it can work to get opinions through these programs. With this theory, the public participation conceptualized the active involvement of citizens in the process of implementation of the Program of PMB-RW stated with participation in decision making, participation in program development, participation in the social movement, and participation in the implementation of various jobs. With this variable operational concept developed 4 dimensions of analysis: (1) the dimension of participation in decision making, (2) the dimension of participation in program development, (3) participation in the social Dimension, and (4) dimensions of participation in the implementation of various work.

The Influence of Empowerment and Community Participation Collectively against Social Welfare.

The dual regression equation of measurement Results of empowerment and community participation collectively against Community welfare is $\hat{\mathrm{Y}}=-6.507+0,600 \mathrm{x}_{1}+0,547 \mathrm{X}_{2}$. The results of this double regression equation measurements showed that the influence of the empowerment of the variable against the welfare of Society $\left(b_{1}\right)=0.600$, influence public participation towards community welfare of $\left(b_{2}\right)=0.547$. From the results of the regression equation of double counting noted that contributions influence Empowerment (0.600) is greater than the contributions of the influence of public participation towards community welfare (0.547). The results of these measurements are acceptable and logical because ultimately that determine success or whether that Empowerment determined by Participation of the community in the performance of the whole affair.

The Value of $\mathrm{F}$ count obtained in the data analysis the influence of empowerment and community participation collectively towards community welfare Recipient PMB-RW in Pekanbaru of 710.073 while the value Ftabel with TTL-level the significance of $5 \%(\alpha=0.05)$ with the $\mathrm{v} 1$ or $\mathrm{dk}$ numerator $=\mathrm{k}=2$ and $\mathrm{v} 2$ or dk denominator $=\mathrm{n}-\mathrm{k}-1=2-1=357-360$ is 
2.62 (attachments). Because Ffemale > Ftable $(710.073>2.62)$, the value of $<0.05$ significance or $0.000<0.05$, then $\mathrm{H}_{0}$ is rejected and $\mathrm{H}_{1}$ is received. Thus, the hypothesis $\mathrm{H}_{1}$ stating "there is the influence of Empowerment and community participation collectively against the welfare of the community" is acceptable.

\section{The Concept of the Discussion of the Influence of Empowerment and Community Participation towards Community Welfare}

There are two concepts that are derived from the discussion of the influence of empowerment and community participation towards community welfare Recipient PMB-RW drive in the city of Pekanbaru. The description of the two concepts are the following:

The concept I: Based on the empirical foundation and theoretical foundation laid out the concept of Provider Opportunities below:

The Definition Of The Concept Of Opportunity and openness of information empowerment socialized to the public especially to the community empowerment which includes the recipient's chances of filing a proposal or activity assistance; capital and support opportunities business facilities; and the opportunity to seek and obtain revenue from the management of capital and facilities support the effort.

Concept Description: Community Empowerment Opportunities a policy scope and simultaneously became the concept of community empowerment mainly poor community groups which demonstrates that the community empowerment opportunities indeed planned clearly and systematically to improve or strengthen the resources of community groups or citizens of the recipient of empowerment. In this context, at least three opportunities must be created for conducting community empowerment effectively. Three opportunities in question are (1) the proposed aid opportunities or activities; (2) capital support opportunities and business facilities, and (3) seek opportunities and earn income.

The Proposition Of The Concept: The chances of proposed aid; the odds got the support of capital and business facilities; the opportunities sought and earned income in the process of community empowerment is an important factor in the improvement of community welfare recipients Assistance Program PMB-RW.

Concept II: Based on the empirical foundation and theoretical Foundation organized the concept of Community Participation In Various Development Work the following:

The Definition Of The Concept Of Community participation in various development work was the role and community involvement are actively in the implementation of policies, programs and development activities that include the construction of the road environment, the construction of social facilities and the construction of public facilities in support of the attainment of community welfare. The definition of this concept includes three dimensions theoretical Dimensions: (1) the construction of the road environment, (2) Dimension social facilities construction, and (3) the dimensions of the construction of public facilities.

Concept Description: The role and community involvement are actively in the implementation of policies, programs and development activities that include the construction of the road 
environment, the construction of social facilities and the construction of public facilities is one of the determinants of the effectiveness of the implementation of policies, programs, and development activities. As one of the determinants of the effectiveness, if managed appropriately and carefully, then the role and community involvement that can give added value to the process and the results of the implementation of policies, programs and development activities. The value added comes from the resource management community. Human resource is the potential of an individual, include the potential of social groups and the potential for viable institutions required to provide added value on the financing, the execution of the work, maintenance or utilization and results in development work. To get a value-added that a consultative approach is required, the coordinative approach, integrative approach, and operational approach. Consultative approach refers to the structural resources i.e. the authority of administrative development. Coordinative approach refers to a functional resource, namely the institutional functions of Government and society that is associated with the implementation of the development. Integrative approach refers to the cultural resources i.e. potential social and local wisdom that positively correlated with performance development. The operational approach i.e. potential professionals needed to carry out the development. Combined approaches are the application of Multidiscipline Comprehensive Outline (CMO) or a comprehensive and integrated approach with raising a variety of needed resources. A comprehensive and integrated approach to optimizing public participation in development which includes the performance of the construction of the road environment, the construction of social performance, and the performance of the construction of public facilities. Three dimensions of development performance can be decrypted as follows: (1) the construction of the road environment; (2) construction of Social Facilities; (3) the construction of public facilities.

The Proposition Of The Concept: Development is the road environment, the development of social facilities, and construction of public facilities that attract public participation is an important factor in the improvement of the welfare of the community acceptance for Assistance Program PMB-RW.

\section{Closing}

The magnitude of the influence of Empowerment to increased community welfare Recipient Program PMB-RW determined by the provision of resources, provision of opportunities, the provision of knowledge, and the provision of expertise. Path coefficient measurement results show that the magnitude of the influence reached 0.78 , entered the category of "strong" and significant. The existence of these influences indicates that among the community empowerment through PMB-RW Program execution with increased community welfare Recipient Program PMB-RW created a causal relationship (causality relations). Causal relationship meaning that if Empowerment is enhanced or increased the empowerment was followed by Increased social welfare Recipient Program PMB-RW. The results of this study confirmed that community empowerment through PMB-RW Program execution can be expressed as one of the factors the causes of increased community welfare Recipient Program PMB-RW in the city Pekanbaru.

The magnitude of the influence of public participation towards the improvement of 
community welfare Recipient Program PMB-RW determined by participation in decision making, participation in the development of the program, participation in social movements, and participation in the implementation of various jobs. Path coefficient measurement results show that the magnitude of the influence reached 0.73 , entered the category of "strong" and significant. The existence of these influences indicates that among the public participation, which took place in the implementation of the Program of PMB-RW with increased community welfare Recipient Program PMB-RW created a causal relationship (relationship causalities). Causal relationship meaning that if community participation improved or increased the empowerment was followed by Increased social welfare Recipient Program PMB-RW. The results of this study confirmed that the public participation, which took place in the implementation of the Program of PMB-RW can be expressed as one of the factors the causes of increased community welfare Recipient Program PMB-RW in the city Pekanbaru.

There is the influence of empowerment and community participation collectively toward the improvement of community welfare Recipient Program PMB-RW drive in the city of Pekanbaru. From the results of measurements of the coefficient of double regression in mind that contributions influence Empowerment (0.594) is greater than the contributions of the influence of public participation (0.543) towards the improvement of community welfare Recipient Program PMB-RW in The City of Pekanbaru.

The concept of the discussion of the influence of Empowerment to increased community welfare Recipient Program PMB-RW drive in the city of Pekanbaru is the development of the concept of community empowerment Opportunities Dimensions. The definition of the concept of the development dimension of community empowerment this Opportunity is an opportunity and openness of information empowerment socialized to the public especially to the recipient community empowerment which includes proposed aid opportunities or activities; opportunities gained support from capital and business facilities; and the opportunity to seek and obtain revenue from the management of capital and facilities support the effort. In this definition covered three theoretical dimensions: (1) the dimensions of the proposed aid opportunities or activities; (2) the dimensions of the support opportunities for capital and business facilities; and (3) the dimension of chance tries and earn income.

The concept of obtained from the discussion of the influence of public participation towards the improvement of community welfare Recipient Program PMB-RW drive in the city of Pekanbaru is the development of the concept of public participation in a variety of Development Work. The definition of the concept of public participation in various development work, it is community role and community involvement are actively in the implementation of policies, programs and development activities that include the construction of the road environment, the construction of social facilities and the construction of public facilities in support of the attainment of community welfare. The definition of this concept includes three dimensions theoretical Dimensions: (1) the construction of the road environment, (2) Dimension social facilities construction, and (3) the dimensions of the construction of public facilities. 


\section{References}

Adi, I. R. (2001). Pemberdayaan, Pengembangan Masyarakat dan Intervensi Komunitas (Pengantar pada Pemikiran Pendekatan Praktis), Jakarta: Lembaga Penerbit FEUI.

Amaluddin, M. (1987). Kemiskinan dan Polarisasi Sosial - StudiKasus di Desa Bulugede, Kabupaten Kendal, Jawa Tengah, Jakarta : pnerbit Universitas Indonesia

Beratha, I. N. (1982). Desa, Masyarakat Desa dan Pembangunan Desa. Jakarta: Ghalia Indonesia.

Chambers, R. (1983). Pembangunan Desa-Mulai Dari Belakang, Jakarta: LP3ES.

Ife, J. (1995). Community Development: creating community alternatives - vision analysis and practice, Melbourne: Longmen Australia Pty Ltd.

Kartasasmita, G. (1996). Pembangunan Untuk Rakyat: Memadukan Pertumbuhan Dan Pemerataan, Jakarta : Pustaka CIDESINDO.

Ndraha, T. (1990). Kybernology (Ilmu Pemerintahan Baru) I , Rineka Cipta : Jakarta

Oakley, P., \& David, M. (1991). Project with People: The Practice of Participation in Rural Development, Geneva : International Labors Office

Pranarka, A. M. W., \& dan Moeljarto, V. (1996). Pemberdayaan (Empowerment), dalam Prijono, Onny S dan Pranarka, A.M.W, Pemberdayaan: Konsep, Kebijakan, dan Implementasi, Jakarta, CSIS.

Sedarmayanti. (2003). Good Governance (Kepemerintahan yang Baik) Dalam Rangka Otonomi Daerah : Upaya Membangun Organisasi Efektif dan Efesien melalui Restrukturisasi dan Pemberdayaan. Bandung : CV. Mandur Maju.

Shardlow, S. (1998). Values, Ethics and Social Work dalam Adam, Robert., Lena Dominelli dan Malcom Payne (eds). Social Work: Themes, Issues and Critical Debates. London: MacMillan Press Ltd.

Soetomo. (1995). Masalah sosial dan pembangunan. Jakarta : PT. Dunia Pustaka.

Soetrisno. (1995). Menuju Partisipasi Masyarakat. Yogyakarta : Kanisius.

Sumodiningrat, G. (1999). Kemiskinan, Teori, Fakta dan Kebijakan, Jakarta : IMPAC.

Todaro, P., Michael dan S., \& Stephen, C. (2003). Pembangunan Ekonomi di Dunia Ketiga, Jakarta : PT. Gelora Aksara Pratama.

\section{Copyright Disclaimer}

Copyright for this article is retained by the author(s), with first publication rights granted to the journal.

This is an open-access article distributed under the terms and conditions of the Creative Commons Attribution license (http://creativecommons.org/licenses/by/4.0/). 